\title{
Methylmalonyl Coenzyme A Racemase Defect: Another Cause of Methylmalonic Aciduria
}

\author{
Ellen Song Kang ${ }^{[22]}$, Philip J. Snodgrass, and Park S. Gerald \\ Department of Medicine, Division of Clinical Genetics, Children's Hospital Medical Center and Gastrointestinal Unit, Department of \\ Medicine, Peter Bent Brigham Hospital and Harvard Medical School, Boston, Massachusetts, USA
}

\section{Extract}

Metabolism of ${ }^{14} \mathrm{C}$-propionate and methylmalonate was severely curtailed in fibroblasts cultured from an infant with massive transient hyperammonemia (1370 $\mu \mathrm{g} / 100$ $\mathrm{ml}$ ), severe metabolic acidosis, and excretion of large amounts of methylmalonic acid (580 $\mathrm{mg}$ at $24^{\circ}$ ). Metabolism of succinate was normal.

Metabolism of methylmalonate was not enhanced by the addition of excessive amounts of the cofactor, 5'-deoxyadenosylcobalamin (DBCC). The DBCC content of the liver was within normal limits.

Homogenates of liver and fibroblasts metabolized methylmalonate approximately one-half as well as control samples when tritiated racemic methylmalonyl coenzyme A (CoA) was added. Inasmuch as L-methylmalonyl-CoA and not D-methylmalonylCoA is the substrate for the enzyme, methylmalonyl-CoA mutase, which converts L-methylmalonyl-CoA to succinyl-CoA, this indicates that the mutase was intact.

Mitochondrial homogenate from liver, in contrast to normal samples, did not incorporate tritium during the metabolism of synthetic methylmalonyl-CoA, which indicates that activity of racemase was deficient.

Activities of the urea cycle enzymes were low but not rate limiting.

\section{Speculation}

A diet low in isoleucine, threonine, methionine, and valine may offer a rational therapeutic approach to other affected patients. The hyperammonemia observed resembles that reported in propionyl-CoA carboxylase deficiency and Reye's syndrome, which raises the possibility of a common denominator in these several disorders.

\section{Introduction}

Excretion of massive amounts of methylmalonic acid in urine in the absence of vitamin $\mathrm{B}_{12}$ deficiency has been described in disease states of genetic origin in infants and children. This abnormality has been ascribed to a deficiency of methylmalonyl coenzyme A mutase (EC 5.4.99.2) activity in the patients reported to date either because of a defect of the apoenzyme or a defective synthesis of the specific vitamin $\mathbf{B}_{12}$ cofactor required by this enzyme. Clinically, these two forms of methylmalonic aciduria are distinguishable since the latter responds to the administration of pharmacologic doses of vitamin $B_{12}$ [13].

Although it has not been observed in patients reported previously, excessive excretion of methylmalonic acid might also occur with a defect of methylmalonyl-CoA racemase (EC 5.1.99.1), the enzyme which catalyzes the step before the mutase reaction.

In the normal state in the metabolism of propionate to succinate, the enzyme, propionyl-CoA carboxylase, carboxylates propionyl-CoA to methylmalonyl-CoA. Inasmuch as methylmalonyl-CoA contains an asymmet- 


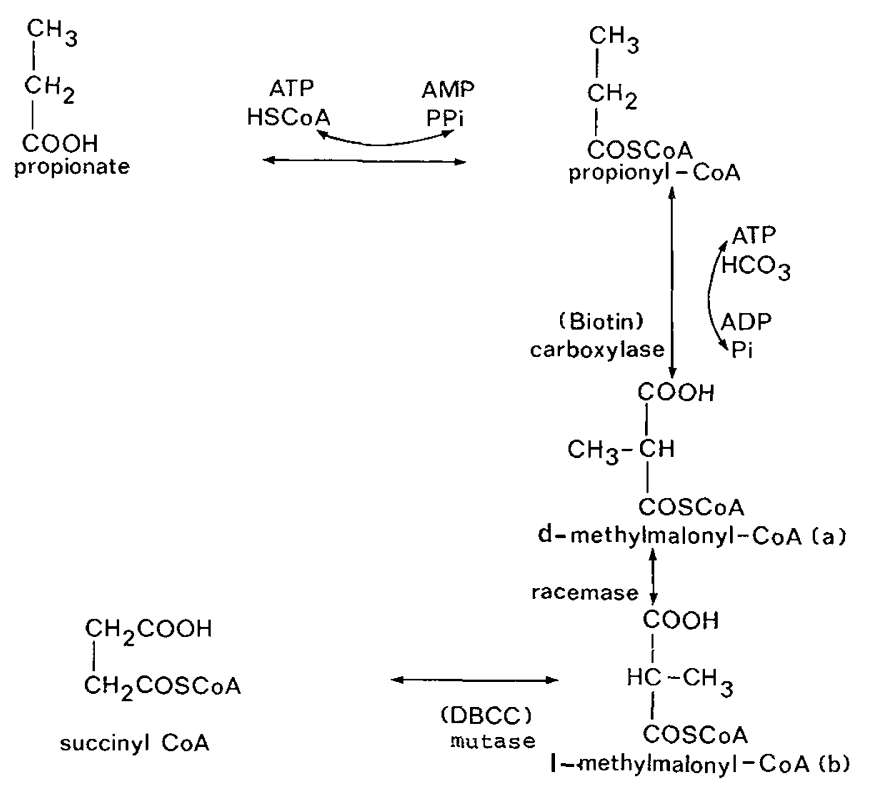

Fig. 1. Propionic acid metabolism in animal tissues. ATP: Adenosine 5'-triphosphate. HSCoA: Coenzyme A thioester. $A M P$ : Adenosine 3'-monophosphate. PPi: Pyrophosphate. COSCoA: Coenzyme A carbonyl thioester. $A D P$ : Adenosine 5'-diphosphate. $P i$ : Orthophosphate. DBCC: $5^{\prime}$-Deoxyadenosylcobalamin. $(a)$ and $(b)$ : Forms $a$ and $b$, see the text.

ric carbon, two isomeric forms of this compound are possible. The steric form resulting from the carboxylation of propionyl-CoA, designated form $a$, must first be converted to its optical enantiomorph by methylmalonyl-CoA racemase, before it can be converted to succinate by the isomerase [10]. Defective racemase activity could therefore result in accumulation of methylmalonyl-CoA (form a) which would result in the increased excretion of methylmalonic acid after nonenzymatic cleavage of the thioester from the acid. (Fig. 1).

\section{Case History}

A newborn infant believed to have such a deficiency in racemase activity has been observed recently. This full term male infant seemed to be normal until 2.5 days of age when he developed progressively severe metabolic acidosis, obtundation, and coma. Hyperammonemia was noted and treated with four exchange transfusions and other supportive measures. Despite these therapeutic attempts he failed to rally and on the 11th day succumbed to overwhelming Klebsiella sepsis. Details of the clinical course and other studies of this infant will be presented elsewhere [7].

\section{Laboratory Methods}

Ammonia was determined by a microdiffusion method [3].

Methylmalonic acid in blood, urine, and tissues was measured by the following modification of the method of Giorgio and Plaut [5]. The column was washed with $50 \mathrm{ml} \mathrm{H}_{2} \mathrm{O}$ and $15 \mathrm{ml} 0.5 \mathrm{~N} \mathrm{HCl}$ before elution of methylmalonic acid with $2 \times 15 \mathrm{ml} 0.5 \mathrm{~N} \mathrm{HCl}$. Then samples were cooled in ice immediately after heating before the addition of alkali.

Skin biopsies were obtained from the patient, his parents, and two normal infants (circumcision). Explants were grown in Dulbecco's modified Eagle Medium or nutrient mixture $F_{10}$ [15] which contained $10 \%$ fetal calf serum and 100 units penicillin $/ \mathrm{ml}$ and $100 \mathrm{mg}$ streptomycin $/ \mathrm{ml}$. Vitamin $\mathrm{B}_{12}$ was not detectable in the Eagle's Medium and was over $5,000 \mathrm{pg} / \mathrm{ml}$ in medium $\mathrm{F}_{10}$ [16].

Fibroblasts were grown to confluence in $60 \mathrm{~mm}$ diameter disposable Petrie dishes, harvested with $0.05 \%$ trypsin which contained $200 \mathrm{mg}$ ethylenediaminetetracetic acid $/ 1000 \mathrm{ml}$, washed twice with phosphate-buffered saline, and centrifuged at $100 \times g$ for $1.5 \mathrm{~min}$ at room temperature after each wash. Cell counts were obtained immediately before each experiment. Fibroblast homogenates were prepared by rapid alternation of freezing and thawing at $37^{\circ}$ five times in 1-2 volumes phosphate-buffered saline.

For study of propionate metabolism, cells or homogenates were incubated in $1 \mathrm{ml}$ Krebs phosphate buffer, pH 7.4, containing $\mathrm{Na}$ propionate- $3-{ }^{14} \mathrm{C}, 0.5 \mu \mathrm{Ci}(0.01$ $\mathrm{mM})$; 2-methyl ${ }^{14} \mathrm{C}$ malonic acid, $0.25 \mu \mathrm{Ci}(0.06 \mathrm{~mm})$; succinic $-1,4-{ }^{-14} \mathrm{C}$ acid, $0.5 \mu \mathrm{Ci}(0.08 \mathrm{~mm})$ at $37^{\circ}$. Cells or homogenates were incubated 3 hours for the propionate and methylmalonate and 2 hours for the succinate experiments. (In the methylmalonate experiments addition of 2.5 to $12 \mu \mathrm{g}$ DBCC did not cause a significant increase in ${ }^{14} \mathrm{CO}_{2}$ evolved.) Unlabeled substrate was added and $\mathrm{CO}_{2}$ was released with $6 \mathrm{~N} \mathrm{H}_{2}$ $\mathrm{SO}_{4}$. The ${ }^{14} \mathrm{CO}_{2}$ evolved was collected in $20 \% \mathrm{KOH}$, added to Liquiflor before radioactivity was determined by scintillation spectrometry [17].

Liver obtained $1 \mathrm{hr}$ after death was kept frozen at $80^{\circ}$ until analysis. Control livers for racemase, mutase, and urea cycle enzymes were obtained from a neonate who died of hyaline membrane disease (several hours after death), an infant with an ornithine carbamyl transferase (OTC) deficiency ( $1 \mathrm{hr}$ postmortem), a 3year-old child with cystinosis ( $12 \mathrm{hr}$ postmortem), and a neonate who died of aortic atresia (12 hr postmor- 
tem). Liver was homogenized in 2 volumes $0.25 \mathrm{M}$ sucrose in the dark. The supernatant obtained after centrifuging at $5,000 \times g$ for $1 \mathrm{hr}$ at $4^{\circ}$ was used.

For the methylmalonyl-CoA studies, liver and fibroblast homogenates were incubated for 20 min with 20 $\mu \mathrm{M}$ Tris-sulfate buffer, $\mathrm{pH} 7.3$, which contained ${ }^{3} \mathrm{H}$ methylmalonyl-CoA, $0.2 \mu \mathrm{Ci}$; DBCC, $12 \mu \mathrm{g} / 1.4-2.7 \mathrm{mg}$ protein. Alkaline hydrolysis, extraction, and separation of methylmalonic and succinic acids were performed as described by Cardinale et al. [2]. The acids were eluted with $0.1 \mathrm{~N} \mathrm{HCl}$ and added to Aquasol; the radioactivity was then measured by scintillation spectrometry.

Mitochondria were isolated from liver tissue according to the method of Hogeboom [6] except that suspension and sedimentation of mitochondria were performed once. The sediment was resuspended in $0.25 \mathrm{M}$ sucrose and subjected to rapid, alternating freeze-thawing 10 times. Homogenates containing $0.9-1.6 \mathrm{mg}$ protein were added to $7 \mu \mathrm{M}$ unlabeled synthetic, racemic methylmalonyl-CoA, $50 \mu \mathrm{l}$ water, and $0.6 \mathrm{mCi}{ }^{3} \mathrm{H}_{2} \mathrm{O}$ and were incubated at $30^{\circ}$ for $25 \mathrm{~min}$. A sucrose blank without protein was also centrifuged to measure spontaneous racemization. Salt-free neutralized hydroxylamine, $1 \mathrm{~mm}$ [8] was added and the mixture was allowed to stand at room temperature for $30 \mathrm{~min}$. Subsequent procedures were carried out at $4^{\circ}$ according to the method of Mazumder et al. [11] except that the supernatant was made $1.0 \mathrm{~N}$ with respect to $\mathrm{NH}_{4} \mathrm{OH}$ before application to a column of Dowex 1-X10 in the chloride form. The eluted methylmalonylhydroxamic acid was dried, taken up in water, and added to Aquasol [18] before a reading was taken by scintillation spectrometer. All values were corrected for spontaneous racemization by subtraction of the sucrose blank value. Total protein was determined by the Lowry method [9].

DL-2-Methyl- ${ }^{3} \mathrm{H}$-malonyl-CoA was synthesized from DL-2-methyl-3H-malonic acid and CoA according to the method of Trams and Brady [14].

The DBCG content was assayed by the dioldehydrase method by Dr. Robert Abeles, Brandeis University, Waltham, Mass. [1].

\section{Results}

Large amounts of methylmalonic acid were found in all samples of urine tested: $580 \mathrm{mg}$ at $24^{\circ}$ compared with $5.8 \pm 4.2 \mathrm{mg}$ at $24^{\circ}$ in normal subjects [5]. The methylmalonic acid concentration of a pooled serum specimen (collected before the initial blood exchange
Table I. Metabolism of labeled propionate, methylmalonate, and succinate of cultured fibroblasts ${ }^{1}$

\begin{tabular}{|c|c|c|c|}
\hline & $\begin{array}{l}\text { Na propionate- } \\
{ }_{3-14} \mathrm{C}, \mathrm{m} \mu \mathrm{M} \mathrm{M}^{14} \mathrm{CO}_{2} \\
\text { evolved } / 10^{8} \\
\text { cells } / 3 \mathrm{hr} \text { at } 37^{\circ}\end{array}$ & $\begin{array}{c}\text { 2-Nethyl-14C } \\
\text { malonic acid, } \\
\text { m } \mu \mathrm{MI} 14 \mathrm{CO}= \\
\text { evolved/10 } \\
\text { cells } / 3 \mathrm{hr} \\
\text { at } 37^{\circ}\end{array}$ & $\begin{array}{c}\text { Succinic- } \\
1,4-\text { - }^{-14} \mathrm{C} \text { acid, } \\
\mathrm{m} \mu \mathrm{sr}{ }^{14} \mathrm{CO}_{2} \\
\text { evolved } \\
\text { cells } / 20^{8} \\
\text { at } 37^{\circ}\end{array}$ \\
\hline Control subject $I^{2}$ & 37 & 29 & 2.0 \\
\hline Control subject $I I^{2}$ & 42 & 24 & \\
\hline Patient & 0.15 & 0.25 & $\mathrm{I} .7$ \\
\hline Patient's father & 24 & & \\
\hline Patient's mother & 10 & & \\
\hline
\end{tabular}

${ }^{1}$ Each value represents the average of two to four assays.

${ }^{2}$ Neonate, circumcision skin.

Table II. Metabolism of labeled methylmalonate of liver ${ }^{1}$

\begin{tabular}{lc}
\hline & $\begin{array}{c}\text { 2-Methyl-14C malonic acid, m } \mu \mathrm{M} \\
\text { metabolized } / \mathrm{mg} \text { protein/3 } \mathrm{hr}\end{array}$ \\
\hline Control subject $\mathrm{I}^{2}$ & 2.12 \\
Control subject II $^{3}$ & 2.13 \\
Patient & 0.15 \\
\hline
\end{tabular}

I Each value represents the average of two to four assays.

${ }^{2}$ Neonate, hyaline membrane disease.

${ }^{3}$ Ornithine carbamylase transferase deficiency.

Table III. Metabolism of tritiated racemic methylmalonyl coenzyme $A$ of cultured fibroblasts and liver ${ }^{1}$

\begin{tabular}{lc}
\hline & $\begin{array}{c}\text { Succinate-3H recovered from } \\
\text { protein } \\
\text { at } 37^{\circ}, \text { dpmogenized cells) }\end{array}$ \\
\hline Fibroblasts & \\
$\quad$ Control subject ${ }^{2}$ & 404 \\
$\quad$ Patient & 290 \\
Liver & \\
$\quad$ Control subject ${ }^{3}$ & 1171 \\
Patient & 565 \\
\hline
\end{tabular}

1 Each value represents the average of two to four assays.

2 Neonate, circumcision skin.

${ }^{3}$ Neonate, hyaline membrane disease.

Table IV. Incorporation of tritium from ${ }^{3} \mathrm{H}_{2} \mathrm{O}$ in to methylmalonyl coenzyme A

\begin{tabular}{lc}
\hline & $\begin{array}{c}\text { Incorporation of } 3 \mathrm{H} \text { from } \\
\text { mitochondrial protein at } 30^{\circ}, \\
\mathrm{dpm} / 10 \mathrm{mg} \text { protein } / 25 \mathrm{~min}\end{array}$ \\
\hline Control subject $^{1}$ & 2,822 \\
Control subject $^{2}$ & 886 \\
Patient & 34 \\
\hline
\end{tabular}

1 Neonate, ornithine carbamyl transferase deficiency.

${ }^{2}$ Neonate, hyaline membrane disease.

transfusion) was high also: $28.8 \mathrm{mg} / 100 \mathrm{ml}$ compared with $0.75 \mathrm{mg} / 100 \mathrm{ml}$ in a control subject. In a postmortem specimen from liver obtained $1 \mathrm{hr}$ after death, 
Table $V$. Activity of enzymes from urea cycle in tissue from liver ${ }^{1}$

\begin{tabular}{lccccc}
\hline \multicolumn{1}{c}{ Source } & CPS & OCT & AS & AL & Arginase \\
\cline { 2 - 5 } & & & $\mu$ moles product/hr/g wet weight & \\
\hline $\begin{array}{l}\text { Eight liver biopsies from normal } \\
\quad \text { adults }\end{array}$ & $279 \pm 65$ & $6600 \pm 1580$ & $90 \pm 12$ & $220 \pm 25$ & $86,000 \pm 9300$ \\
$\begin{array}{l}\text { Liver from patient } \\
\text { Female } 3 \text { days old }\end{array}$ & 202 & $1830(28 \%)$ & $22.4(25 \%)$ & $63.6(29 \%)$ & $12,500(14.5 \%)$ \\
\hline
\end{tabular}

${ }^{1}$ CPS : Carbamyl phosphate synthetase. OCT: ornithine carbamyl transferase. AS : argininosuccinate lyase. AL: argininosuccinate lyase.

${ }^{2}$ Liver obtained within $\mathrm{l} \mathrm{hr}$ after death and frozen at $-80^{\circ}$ for 10 days before assay. Each enzyme assayed at two concentrations of $5 \%$ homogenate. All duplicates agreed within $5 \%$. A fresh liver from a rat on $8 \%$ casein diet assayed for quality control gave expected results.

${ }^{3}$ Congenital heart disease. Liver obtained $12 \mathrm{hr}$ after death and frozen at $-80^{\circ}$ for 25 days before assay [13].

the concentration of free and total methylmalonic acid was 0.63 and $2.17 \mathrm{mg} / \mathrm{g}$ wet weight, respectively, compared with 0.17 and $1.46 \mathrm{mg} / \mathrm{g}$ wet weight in a control subject.

The content of DBCC in liver was within normal limits (70 and $50 \mathrm{~m} \mu \mathrm{g} / \mathrm{g}$ wet weight on two separate assays: normal value, $67-240 \mathrm{~m} \mu \mathrm{g} / \mathrm{g}$ wet weight) [1].

The metabolism of ${ }^{14} \mathrm{C}$-labeled propionate and methylmalonate was severely curtailed in fibroblasts cultured from the patient, whereas metabolism of succinate was normal (Table I).

Metabolism of these substrates by liver homogenates are similarly reflected in Table II.

Fibroblasts and homogenates from liver metabolized added tritiated racemic methylmalonyl-CoA half as well as control samples (Table III).

Mitochondrial homogenates from liver incorporated insignificant amounts of tritium when they were incubated with synthesized unlabeled methylmalonyl-CoA and tritiated water, in contrast to normal control homogenates (Table IV).

Ornithine carbamyl transferase activity, argininosuccinate synthetase (AS) activity, argininosuccinate lyase (AL) activity, and arginase activity were $15-30 \%$ of normal but not rate limiting and carbamyl phosphate synthetase (CPS) activity was within the range for normal adults (Table $V$ ).

\section{Discussion}

Results of ${ }^{14} \mathrm{C}$-propionate, methylmalonate, and succinate metabolism of cultured fibroblasts and liver homogenates indicate the presence of a block in the conversion of methylmalonate to succinate which could be due to either defective mutase or racemase activity, or, remotely, to a combination defect of the two enzymes.

Deficiency of mutase activity can result either from an apoenzyme defect or from subnormal concentration of intracellular cofactor (which can, in turn, be due to defective cofactor metabolism or to diminished transport of the cofactor or appropriate $\mathrm{B}_{12}$ precursor). Problems of transport and metabolism of vitamin $\mathrm{B}_{12}$ were eliminated by incorporating into our methods the following findings: metabolism of methylmalonate by homogenates of liver and intact or homogenized fibroblasts was not corrected by the addition of excessive amounts of the cofactor, $5^{\prime}$-deoxyadenosylcobala$\min$.

Mutase deficiency was eliminated by demonstration of the ability of homogenates of liver and fibroblasts to metabolize tritiated DL-methylmalonyl-CoA (Table III). Chemically synthesized methylmalonyl-CoA is approximately a 50/50 mixture of forms $a$ and $b$ [11]. In the liver homogenate studies, the amount of racemic methylmalonyl-CoA converted to succinate was approximately half that of the control sample (Table III). Homogenates of fibroblasts converted somewhat more DL-methylmalonyl-CoA to succinate. (The reason for this augmented activity in fibroblasts has not yet been clarified but studies are currently in progress to explore this.)

The mechanism of racemization has been shown to occur by ionization and shift of the $\alpha$-hydrogen atom [4]. Mazumder et al. [11] first observed the incorporation of tritium from ${ }^{3} \mathrm{H}_{2} \mathrm{O}$ into methylmalonyl-CoA during racemization. The uptake of the proton during metabolism of synthetic methylmalonyl-CoA can be readily demonstrated with homogenates of control liver (Table IV). The uptake of tritium with mitochondrial homogenate from liver of the patient was insignificant (Table IV).

In view of the hyperammonemia of the patient, enzymes of the urea cycle were measured. The low OCT, $\mathrm{AS}, \mathrm{AL}$, and arginase activity may be due to the poor 
intake of protein and high intake of glucose by the infant. None of the enzyme activities was rate limiting.

Theoretically, these findings could result from a combined lesion involving the racemase enzyme and a partial defect of the mutase. Such a combination would be difficult to imagine since partial defects (heterozygotes for the mutase defect) are not known to accumulate methylmalonic acid to any significant degree.

These findings support the diagnosis of a deficiency of methylmalonyl-CoA racemase and indicate that this new disorder should be considered in the differential diagnosis of patients with methylmalonic aciduria which is unresponsive to vitamin $B_{12}$.

\section{Summary}

A neonate with hyperammonemia, acidosis, and coma was found to have methylmalonic aciduria and defective propionate to succinate metabolism. The metabolic defect resulted from impaired ability to convert methylmalonyl-CoA (form a) to its optical isomer, methylmalonyl-CoA (form $b$ ) because of a deficiency of methylmalonyl-CoA racemase activity.

\section{References and Notes}

1. Abeles, R. H., Myers, C., and Smrth, T. A.: An enzymatic assay for the determination of millimicrogram quantities of $B_{12}$-coenzyme. Anal. Biochem., 15: 192 (1966).

2. Cardinale, G. J., Dreyfus, P. M., Auld, P., and Abeles, R. H.: Experimental vitamin $B_{12}$ deficiency: its effect on tissuc vitamin $B_{12}$-coenzyme levels and on the metabolism of methylmalonyl-CoA. Arch. Biochem. Biophys., 131: 92 (1969).

3. Conway, E. J., AND O'Malley, E. Microdiffusion methods: ammonia and urea using buffered absorbents (revised method for ranges greater than $10 \mu \mathrm{g} \mathrm{N}$ ). Biochem. J., 36: 655 (1942).

4. Overath, P., Kellermann, G. M., Lynen, F., Fritz, H. P., AND KELLER, J:: The mechanism of the rearrangement of methyl-coenzyme A and succinyl-coenzyme A: II. studies on the mode of action of methylmalonyl-coenzyme $\mathrm{A}$ isomerase and methylmalonyl-coenzyme A racemase. Biochem. Z., 335: 500 (1962).

5 Glogio, A. J., and Plaut, G. W. E.: A method for the colorimetric determination of urinary methylmalonic acid in pernicious anemia. J. Lab. Clin. Med., 66: 667 (1965).

6. Носевоом, G. H.: Isolation of intact mitochondria. In: S. P. Colowick and N. O. Kaplan: Methods in Enzymology, Vol. I, p. 16. (Academic Press, New York, 1955).

7. Kang, E. S., Snodgrass, P. J., Cowett, R. M., O'Tuama, L., Desai, N., ANd Gerald, P. S.: Methylmalonyl-CoA racemase deficiency and hyperammonemia (Manuscript submitted).

8. Kaufman, S.: Studies on the mechanism of the reaction catalyzed by the phosphorylating enzyme. J. Biol. Chem., 216: $153(1955)$.

9. Lowry, O. H., Rosebrough, N. J., Fark, A. L., and Randar.., R. J.: Protein measurement with the Folin phenol reagent. J. Biol. Chem., 193: 265 (1951).

10. Mazumder, R., Sasakawa, T., Kaziro, Y., and Ochon, S.: A new enzyme in the conversion of propionyl-coenzyme $A$ to succinyl-coenzyme A. J. Biol. Chem., 236: PC53 (1961).

11. Mazumier, R., Sasakawa, T., Kaziro, Y., and Ochoa, S.: Metabolism of propionic acid in animal tissucs. J. Biol. Chem., 237: 3065 (1962).

12. Nuzum, C. T., and Snodgrass, P. J.: Urea Cycle enzyme adaptation to dictary protein in primates. Scicnce, 172: 1042 (1971).

13. Rosenbers, L. E., Lili.jeQvist, A., And Hsis, Y. E.: Methylmalonic aciduria, an inborn crior leading to metabolic acidosis, long chain ketonuria and intermittent hyperglycinemia. New Engl. J. Med., 278: 1319 (1968).

14. Trams, E. G., and Brady, R. O. The synthesis of malonyl-C ${ }^{1+4}$ coenzyme A. J. Amer. Chem. Soc., 82: 2972 (1960).

15. Grand Island Biological Co., Chagrin Falls, Ohio.

16. Vitamin $B_{12}$ assays were performed by New England Medical Laboratories, Inc., Franklin, Mass.

17. Packard Tri-Carb liquid scintillation spectrometer, Packard Instrument Co., Dawers Grove, Ill.

18. New England Nuclear, Boston, Mass.

19. Permission was obtained for these studies in accordance with the requirements of the United States Public Health Service.

20. The present address of Dr. E. S. Kang is: University of Tennessee, Dobbs Research Institutes, 951 Court Avenue, Memphis, Tennessee 38103.

21. This work was supported in part by the Children's Hospital Medical Center Mental Retardation and Human Development Research Program (HD 03-0773) by United States Public Health Service Grants nos. HD-04807 and AM-14838 and by a research grant from the John A. Hartford Foundation, Inc.

22. Request for reprints should be addressed to: Ellen Sonc, KANG, M.D., University of Tennessee, Dobbs Research Institute, 951 Court Avenue, Memphis, Tenn. 38103 (USA).

23. Accepted for publication August 21, 1972. 